\title{
Emotions in Hannah Arendt's Public Space
}

\author{
Iana Lepetiukhina \\ PhD Student, Immanuel Kant Baltic Federal University \\ Address: A. Nevskogo str., 14, Kaliningrad, Russian Federation 236016 \\ E-mail: iana.lepetiukhina@gmail.com
}

\begin{abstract}
The article is dedicated to the role of emotions in the political theory of Hannah Arendt. Her thoughts on emotions turn out to be a stumbling block for most contemporary defenders of emotions in politics, and many of Arendt's opponents and critics focused on her ideas on emotions in order to refute or reinterpret them. However, being separated from the crucial concepts of Arendt's theory, emotions cause confusion. Therefore, the approach displayed in the article implies a discovery of their influence on public space and plurality, as well as on other significant concepts in Arendt's theory. Plurality, as a precondition of public space, is manifested by means of the uniqueness of speech and actions, and any appeal to common emotions as the foundation of a better public realm leads to the absence of plurality and uniqueness. Thus, the suggested treatment allows demonstrating a correlation between emotions and politics and, moreover, distinguishing the alternatives of emotions in politics, such as solidarity instead of compassion, or courage instead of fear. In addition, the ideas of understanding and reconciliation with the world are examined in order to demonstrate their significance for the existence of plurality and public space, unlike those emotions that destroy both of them.
\end{abstract}

Keywords: emotions, compassion, solidarity, reconciliation, love, fear, courage, Hannah Arendt

Describing certain emotions and their role in politics Hannah Arendt underlines their antipolitical character and their worldlessness. Emotions such as love, compassion, pity, and fear do not belong to the world, but rather to the political world, they are irrelevant and corrosive for politics. However, Arendt does not entirely exclude emotions from the public realm, she admits that some of them, such as joy, pleasure, rage, and laughter do appear as public emotions. ${ }^{1}$ Peg Birmingham, in her article "Hannah Arendt's Dismissal of the Ethical" dedicated to the elimination of ethics and passions from politics, emphasized that "the passion which is properly political must have two essential political characteristics, namely, openness to others and plurality" (Birmingham, 1995: 138). Indeed, compassion, love, pity, and fear do not fulfill these criteria of openness to others and plurality which are both necessary for the existence of politics and public space. Arendt's split between public/private emotions and her reflections on superfluous emotions in

(C) Iana Lepetiukhina, 2018

DOI: 10.17323/1728-192X-2018-4-117-130

(c) Centre for Fundamental Sociology, 2018

1. For instance, Arendt mentioned laughter and pleasure in her essay "On Humanity in Dark Times: Thoughts about Lessing." Both of these emotions are connected to a reconciliation with the world, where laughter "helps one to find a place in the world, but ironically, which is to say, without selling one's soul to it" (Arendt, 1970: 6). While pleasure is the result of a profound awareness of the world, that is aroused by "a passionate openness to the world and love of it" (Ibid.: 6). In the upcoming article, the politically relevant emotions will be analyzed in details. 
politics caused lively discussions both among many of the modern defenders of emotions in politics and her contemporaries.

Soon after a publication of Eichmann in Jerusalem: A Report on the Banality of Evil, many readers blamed Arendt for her heartlessness. For instance, Gershom Scholem in his letter (Arendt, 2007: 465) suggested that Arendt lacked "love of the Jewish people." Answering to Scholem, Arendt mentioned that "the role of the 'heart' in politics seems ... questionable" (Ibid.: 467), because the reporting of certain unpleasant facts has always been charged as the lack of soul or lack of heart. Besides, she underlined that emotions often "conceal factual truth" (Ibid.: 467). Such a concealment of truth causes the distortion of common reality, and may even lead to its destruction which is more crucial for Arendt than any public expressions of emotions.

A number of critics further paid special attention to Arendt's elimination of emotions from politics. Among them is George Kateb, who wondered how the author of The Origins of Totalitarianism could purge "true politics of love, goodness, conscience, compassion and pity?", or how Arendt could charge compassion and pity "as the sponsors of more cruelty than cruelty itself" (Kateb, 1984: 29). Kateb's position was carefully considered by Margaret Canovan in her book Hannah Arendt: A Reinterpretation of Her Political Thought, where Canovan emphasized the incorrect context of Kateb's understanding. Canovan argued that Kateb (as well as Bhikhu Parekh and Peter Johnson ${ }^{2}$ ) assumed Arendt's theory of action and the book The Human Condition was the centre of her political thought (Canovan, 1992: 156), while in order to understand Arendt's position the proper starting point is not The Human Condition but The Origins of Totalitarianism (Ibid.: 157). Canovan demonstrated Arendt's search for safeguards against totalitarianism, although it was not religion or morals but Socrates' "internal dialogue" of thought that "had great moral significance for the individual" (Ibid.: 162), particularly in the period of political crisis, or the "dark times," as Arendt titled it after Brecht's usage.

Another interpretation of Arendt's coldness and heartlessness was considered by Deborah Nelson in her article dedicated to Mary McCarthy and Hannah Arendt. Nelson underlined the popular opinion regarding the seeming-callousness of both authors' views and their indifference to suffering. Nelson argued that pain and suffering were the significant ethical and political questions for both, though instead of seeking a relief from suffering, they were focused on the "heightened sensitivity of reality" (Nelson, 2006: 88), because the consolation for suffering in warm emotions and empathy turns out to be anesthetic (Ibid.: 88) which separates oneself from reality. Therefore, the tolerance of suffering and pain causes a deeper understanding of reality. Nelson underlines that McCarthy and Arendt chose to face reality despite its ability to hurt. Thus, "facing reality" as Nelson called it, instead of escaping it, causes a reconciliation of the world. Reconciliation means accepting the world as it is, with its pain, suffering, wrongs, and evil.

Thus, the role of emotions can be defined through the crucial concepts and ideas in Arendt's theory. The meaning of emotions cannot be considered separately since they

2. See their works: Parekh, 1981; Johnson, 1988. 
play a huge, though negative, role in Arendt's definition of politics. The political sphere in Arendt's theory is exactly that place where people are able to speak with each other, and appear through their speech and actions in reality between them. The absence of emotions in public creates the outer space between in order to speak with others but it also creates the space within in order to be able to speak with oneself despite any feelings and passions. In order to speak with others, one has to be able to speak with oneself, or rather, to think. There is no way of creating "space between us without at the same time creating space within us" (Parekh, 1981: 94). Therefore, emotions prevent the creation of a genuine political realm.

Despite the miscellaneous critique of the elimination of emotions in Arendt's thought by unfairly charging her with heartlessness and callousness, the analysis of emotions along with morality and ethics occupies a "central place in her canon" (Mahony, 2018: 2) as well as politics but it still requires an accurate and proper analysis. The dominance of approaches to political topics rather than of morals and ethics is caused by Arendt's interpretation of herself as a political theorist (Arendt, 2005a: 1). Deirdre Mahony argues that many political interpretations encompass ethical dimension (Mahony, 2018: 4) though this area of studies is about "ethics within Arendtian politics rather than Arendtian ethics per se" (Ibid.: 4), and suggests considering Arendt's ethical thought separately from politics.

In my opinion, it is worth analyzing emotions in the way they appear in Arendt's works in their connection with her ideas of plurality and publicity as essential parts of the political realm. Such an approach allows us to demonstrate the correlation between emotions and politics, and indicates alternatives of emotions in politics, such as solidarity instead of compassion, or courage instead of fear (Degerman, 2016: 11).

\section{The Obscured World of Emotions}

In her last book, The Life of the Mind, Arendt distinguishes the life of the soul that cannot appear in the world, and the life of the mind that can be articulated and presented into the world through speech. Both of them are traditionally considered as hidden or as the inner life, since mind and soul are opposed to the body due to their invisibility. However, Arendt discerns them: the life of the mind can be articulated through the inner dialog, while the life of the soul always remains hidden and is "more adequately expressed in a glance, a sound, a gesture, than in speech" (Arendt, 1981: 31). Any demonstration of emotions, feelings, or passions turns out to be a reflection about inner experience rather than the experience itself. Emotions themselves can never become "part and parcel of the world of appearances than can our inner organs" (Ibid.: 31). If anything appears in the outer world, it is always manifested through the operation of thought.

Appearance of emotions in the outside world is an act of self-presentation, since only the bearer of emotions decides that which is worth presenting. A person interprets and judges the processes of the soul by means of the mind. The awareness of emotions allows a person to interpret them, and then to let them appear in the world. The reflection 
of the emotions gives them "the highly individualized form" (Ibid.: 31) because, due to that reflection, they enter the sphere of appearances for which the individualization of phenomena is essential. Without reflection, the expression of emotions is similar to their demonstration among the higher animal species, through inarticulate sounds, glances, or gestures. Reflection allows emotions to be expressed in the world as a unique individual experience.

Human beings present themselves as unique individuals in their deeds and words, and thus "indicate how they wish to appear" (Ibid.: 34). To have a choice what to demonstrate and what is to remain hidden is a specifically human feature. Although possessing the same emotions, people show them differently; otherwise, human beings would speak and act alike (Ibid.: 34). In this way, the presentation of the life of the soul cannot be possible without the mind and its operations. Besides, there is always a hidden motive underlying that conscious choice of the image to be shown.

That difference between emotions and their image creates the space where self-presentation is open to hypocrisy. According to Arendt, such hypocrisy is connected with the Socratic statement "Be as you wish to appear" (Ibid.: 37), which implies to appear always in that way as one wishes to appear, even if "it happens that you are alone and appear to no one but yourself" (Ibid.: 37). Eventually, such an appearance refers to the deliberated choices of many potential images. Once that image is presented among others, then it becomes a lasting and inseparable characteristic of personality, or as its identity.

As the image presents the hidden emotions in the sphere of appearances, they become individual features of the person which they chose to present for interpretation and perception by others. For instance, a hidden fear can be presented as courage, and it becomes a manifested image of a certain personality. To be a courageous person does not mean that the fear in one's soul was overcome, but it means that a person decided not to show the fear once and for all (Ibid.: 36).

Arendt emphasizes the difference between self-presentation and a genuine "thereness" of existence. The discovering of hypocrisy or pretense does not lead to the authentic essence of being, but indicates and destroys the deception itself. Authentic "thereness" of existence cannot appear "to either the inner or the outward sense" (Ibid.: 39) because the inner information does not possess "permanent features which, being recognizable and identifiable, characterize individual appearance" (Ibid.: 39). Emotions and other "inner sensations" cannot be clearly perceived, acknowledged, and identified due to their lack of stability and ephemeral nature. Constant emotions or passions, a permanent mood or sensation are the signs of the serious mental disorder. Therefore, emotions turn out to be "unworldly," since they lack the permeability and duration that are crucial characteristics of the world.

Human beings do not control their emotions, passions, or feelings, but suffer (pathein) them (Ibid.: 72). Moreover, the cases of an increased intensity of the inner processes may even become overwhelming, as, for instance, pain or pleasures (Ibid.: 72). People cannot control emotions because they are similar to the internal organs, whose processes people are aware of but cannot manage. As the opposite to the passiveness of the soul, the life of 
the mind is genuinely active, can be controlled, or "started or stopped at will" (Ibid.: 72). Feelings and emotions are always caused by outer events that affect the soul and produce reactions which cannot be changed through an effort of will. Traditionally, the mind was supposed to rule over the soul's processes, as if the mind was the "souls" highest organ" (Ibid.: 72). Arendt believed that making a soul and a mind equal will give the passive soul "the powerful sovereignty of the mind" (Ibid.: 72).

On the contrary to the passive reactions of the soul, the mind always transforms the objects of its attention. Reflection as an essential feature of the mind creates the space between the givenness of the objects and specific mind's activity of its inner dialog that transforms the sheer givenness of the objects into speech, in contrast to any unruled reactions. "Thought without speech is inconceivable" (Ibid.: 32) means that the mind, contrary to the soul, may appear in the world by means of unique speech, and cause the space between - a sign of reality of the world and the self. While the obscured emotions remain outside the common world due to their passive essence and their potential destruction of the space between, it is crucial for common world people to share with each other.

Arendt sums up her reflections on emotions and their role in the appearance/being, and mind/soul problem in The Life of the Mind. In a number of previous works, Arendt considered certain emotions in their relation to public space, politics, and plurality. Additional special attention will be paid to Arendt's ideas on compassion, love, and fear.

\section{Compassion and Solidarity}

In the letter to Gershom Scholem, Arendt underlined that emotions which are displayed in public become a significant factor in human affairs. She mentioned her book On Revolution where she analyzed the role of emotions, particularly compassion, in politics. She felt pity for Scholem as he had not read her book before he began accusing Arendt of her heartlessness.

Indeed, On Revolution includes a profound critique of compassion as the emotion that influenced and distorted almost all revolutions excepting the American Revolution. Arendt argued that Rousseau introduced compassion into political theory, and that Robespierre brought it onto the stage of the French Revolution (Arendt, 1990: 81). In her opinion, after the French Revolution, compassion became a devastating motive underlying the actions by all subsequent revolutionaries. Moreover, compassion corrupted revolutions, since their aim - the establishment of a new political order - was replaced by urgent social problems, and the immediate search of solving these problems.

The irrelevance of compassion in politics is connected with a few inevitable factors. First of all, compassion "abolishes the distance, the worldly space between men where political matters" (Ibid.: 86). The meaning of politics is connected to the common interest in the world that takes place in the case when "someone talks to somebody about something" (Ibid.: 86), i.e., something is a kind of interest for both and creates the space between, whereas compassion is focused entirely on the sufferings of a certain person. Compassion ruins that space between because suffering replaces the common world 
about which people are able to speak argumentatively. At the same time, suffering cannot be discussed since it requires an immediate cessation of the discussion. Therefore, compassion is absolutely alien to the all kinds of argumentative dialogues necessary for politics.

Secondly, it is implied that compassion cannot use political methods, and remains without any political consequences. Arendt argued that compassion displayed in public turns into pity because compassion exists only in private life, and is always focused on a specific suffering or a particular person (Ibid.: 90). This is why pity directed towards the masses becomes a public perversion of compassion. Pity is able to keep the distance between people but it does not create that worldly space between, because the existence of sufferings and misfortune is necessary for pity; without them, pity cannot exist. When such pity becomes a kind of virtue or a principle of actions, it always glorifies its cause, namely, the suffering of others (Ibid.: 89). Therefore, Arendt charged pity as the sentiment which "possess a greater capacity for cruelty than cruelty itself" (Ibid.: 89), which is exactly why this idea outraged George Kateb and influenced his critique. When pity enters politics, it requires suffering in order to justify itself.

Demonstrating emotions in public and making them a political principle causes another difficulty, particularly, the problem of motive. Displayed motives are destroyed in their own essence, since they are not intended to appear. When inner motives enter the sphere of appearances, they become the objects of suspicion, unlike speech and actions which are meant to appear (Ibid.: 96). The genuine motives of any actions and words cannot be displayed; they always remain hidden because of their appearance through speech and their interpretation again conceals the real motives. Any appeal to the motives in public is always at risk of being accused of hypocrisy and deception.

Motives as well as emotions inhabit the darkness of a human's heart, and always remain hidden. By darkness, Arendt means not only the concealment from others, but even from one's own self. It is connected with the fact that people as witnesses and bearers of their own emotions and motives cannot be sure in their reality as long as the sense of reality is always "bound up with the presence of others" (Ibid.: 96). Thus, the reality of hidden emotions remains doubtful even for their bearers. Such hidden-ness turns out to be a significant feature of a human's inner life, and, therefore, an authenticity of presenting emotions in public raises doubts. Arendt mentioned Robespierre's suspicion and mistrust of others because his sentimental political principles forced him to play a role of "incorruptible" (Ibid.: 97) to demonstrate his virtues, while the life of the heart has its own inner logic that breaks down once it appears in the public light. Thus, Arendt supposed that Robespierre, witnessing his inner life, knew full well that its display may have been a pretense.

A permanent demonstration of emotions in public requires their duration, or rather a constant pretense of having them. Therefore, due to the transience of any emotion, they cannot become a political principle and guide political actions. Once Robespierre made compassion the guiding principle, it ruined any other political principles because Robespierre "did not accept any limitations" (Ibid.: 90). The goal of compassion as a political 
principle was the elimination of suffering, which could be reached only by violent and swift means. Arendt underlined that the aim to dispose of suffering did not include an impartiality of justice towards different social groups, and led to cruelty in order to put an end to the suffering of the poor. Suffering was recognized as poverty, and compassion brought the obscured and miserable le peuple, into the public light, while "high society" was blamed for its indifference towards the distress of the crowd. That is why the rules applied to the rich and the poor were different, and could not have led to social justice and political equality.

The alternative to compassion in politics (Ibid.: 88), "a community of interest with oppressed and exploited" (Ibid.: 90), may be established without any previous appeal to emotions only because of solidarity. Though compassion and suffering may influence the appearance of solidarity, it is not guided by them. Moreover, solidarity has a sense of equality in its essence that allows it to be focused equally on opposite social groups and phenomena. For instance, Arendt underlined that solidarity may comprehend both misfortune and happiness equally for the rich and the poor; it needs none of them in order to justify its own existence, unlike pity that cannot exist without misfortune. Due to its independence and permanent characteristic, solidarity becomes a principle that guides and inspires actions and is liberated from solving immediate problems, but which is founded on common interests and ideas.

Solidarity as a political principle comprehends a multitude of people, not as suffering depersonalized unity, but as a plurality of unique and different individuals. Such an ability of solidarity allows it to comprehend the common world with its inhabitants. Roger Berkowitz emphasized this feature of solidarity that is connected to the reconciliation with the world and to the constitution of common interests among differences (Berkowitz, 2017: 14). Compassion and pity are not focused on individuals themselves, but on certain experiences of their suffering. Therefore, compassion and pity cannot be political principles since they do not bring individuals onto the public space, but only their impersonal misfortunes. Only solidarity turns out to be the result of reconciliation and understanding of the world as it is, with all of its suffering and wrongs. Compassion and pity are the impulsive responses to all wrongdoings without understanding and reconciliation because compassion and pity do not have the ability to comprehend reality manifoldly, but only specific parts of it. Reconciliation with the common world has its crucial political consequence; it brings polis into being (Ibid.: 14). Despite the plurality and differences, there is still a common world that people share with each other. Compassion and pity towards the poor denies the world its fullness with a distortion of common reality, as reality becomes an outcome of certain narrow issues. This is why Arendt criticized Bertold Brecht and one of his fundamental emotions, that of compassion (Arendt, 1970: 235). Arendt underlined that it was compassion that brought Brecht to reality, but almost destroyed his poetry. The significant feature of reality that Brecht discovered was its obscurity. For Brecht, the suffering of the poor was connected to an absolute despair because of their invisibility. Furthermore, compassion towards the distressed determined 
Brecht's political choices, influencing his commitment to the Communist Party, and his acceptance and support of its values and ideology.

Brecht's decision to join the Communist Party was influenced by his belief that the obscured could be brought to the light, and the bad world could be changed into a good one. However, Arendt blamed Brecht for his support of the Party in their period of crimes and abuses. Arendt charged Brecht as a poet as well because he remained silent, and the main responsibility of poets is to tell the truth. She claimed that it was compassion that made Brecht blind, and his silence and inability to reveal the truth were the parts of a corrupted public sphere. Brecht brought suffering and the obscured people into the light in his poems, but he did not expose the Party's outrages.

Brecht supposed that the Communists would focus on the obscured people, and that sufferers would be more significant than any of the Party's failures. In the poem An die Nachgeborenen, Brecht expressed the hope for the end of dark times, when people would be the helpers of each other. His hope was connected with the belief in Communism of its focus on equality and future global happiness. Thus, Brecht was not only obsessed with compassion, but with a belief in equality, solidarity, and friendship between people. However, for Arendt, it was obvious that the belief in Communism's putting an end to suffering led to the obscurity of the public space: once obscured people with their life circumstances are brought into the public light, the public light gets dark.

Thus, the reality that Brecht discovered due to his compassion was not the real one. For Arendt, reality is always the presence of others, while the focus on the poor and the distressed did not involve the others and their interests. Therefore, Brecht's reality was concealed and did not take place in the public space. It caused the problem of understanding the world as it is and the reconciliation with it: the solidarity that Brecht hoped for could not happen without a reconciliation with all the differences and uniquenesses of the world. Solidarity presumes justice for all because it comprehends all, while compassion is focused on the conditions of the unfortunate.

In the essay "On Humanity in Dark Times: Thoughts about Lessing," Arendt emphasized the distinction of the states of the wretched and those "whose different position in the world imposes on them a responsibility of the world" (Arendt, 1970: 15). The distressed, due to their suffering, cannot participate in the common world affairs since they lack the sense of the common reality. In the absence of reality, namely, in extremely dark times, goodness, compassion, and warmth replace the sense of the common world. Only in the state of worldlessness and unreality is where "it is easy to conclude that the element common to all men is not the world, but "human nature" of such and such a type" (Ibid.: 16). The element which is common to all people can be interpreted differently; for instance, it can be the ability to think or to feel, or the ability to be compassionate. However, the only real and common element all people share with each other is the world. The conditions of the poor will not be improved owing to compassion, but because they are the part of the common misfortune of the world. 


\section{Love for the World}

Elisabeth Young-Bruehl emphasized that Hannah Arendt never wrote anything dedicated entirely to love (Young-Bruehl, 2006: 204), although Arendt dedicated her dissertation to the concept of love in Saint Augustine's works, partially elaborated her ideas on love in The Human Condition, and mentioned it in On Revolution, The Life of the Mind, Denktagebuch, and in various essays. The crucial features of love for Arendt are its worldlessness and antipolitical character. Love destroys the significant space "in-between which relates us to and separates us from others" (Arendt, 1998: 242). Without that space between, public realm cannot exist, and neither does a sense of reality. It requires the presence of others, but not everyone or everything is able to withstand the constant presence of them. Therefore, when love enters the sphere of appearance, it "is extinguished, the moment it is displayed in public" (Ibid.: 51). Love and many other great things may survive only in the private sphere (Ibid.: 51). The essence of love is in its worldlessness, and once it is used as political principle in order to change or save the world, love becomes distorted and appears in public as false.

Arendt, in her dissertation Der Liebesbegriff bei Augustine, pointed out that "the world constituted as an earthly world not just by the works of God but by "the lovers of the world," that is, by men, and by what they love" (Arendt, 1996: 17). To love the world means to constitute the world as a human's home. However, in Arendt's dissertation, the manmade world is considered as evil. The wrong love of men for that world is called cupiditas, while the good love as a tie between man and God is called caritas. Though, both kinds of love are different in their objectives, they have a craving desire, or appetitus, in common. Therefore, the human being as such does not have a constant nature and cannot be defined, because human beings are always identified through their desires towards the outside world. Peg Birmingham emphasized that "for both Augustine and Arendt there is no fixed human nature, given once and for all; instead, human beings are always transformed by the objects of their desire" (Birmingham, 2006: 79). Thus, the objects of love can identify the essence of human beings, and love towards God entails love towards oneself as God's creature and towards all other creatures (Arendt, 1996: 140).

Arendt returns to the concept of love in Augustine in The Human Condition where she reflects on the principles which allow the keeping of the human's community strong and tight. Arendt argued that the aim to discover strong bonds between people in order to replace the common world was "the main political task of early Christian philosophy" (Arendt, 1998: 53). Charity, or caritas, as proposed by Augustine, was exactly that principle that could unite not only Christians but all human beings in community. While charity is able to found a community only in the situation of worldlessness, such relationships occur in cases when there is no public space between people. The connection founded on charity has an unworldly character, and Arendt emphasized that the Christian community had always been non-public and non-political (Ibid.: 53). The community that is founded on charity and neighborly love could never become a political one. The alienation of the world in Christianity is connected with the assumption that the world cannot 
last, and that the human's artifice is "a product of mortal hands" (Ibid:54). The common world people share with each other has to transcend the lifetimes of mortal human beings. That is why the Christian world is not the common world at all since it exists under another time, in another space, and with other relationship conditions. When the Christian world contacts the political world, the interaction destroys its very essence since it threatens the potential earthly immortality of the common world, politics, and public space. The continued existence of the earthly world makes it common to all people and to their predecessors and descendants, and only the ability of the earthly world to last transforms the alien outside world into the man-made home.

Worldlessness is the result of the atrophy of both the common sense that helps people to orientate in the world and "the sense of beauty, or taste, with which we love the world" (Arendt, 1970: 13). Without the taste and ability to judge, it is impossible to love the world as it is with all its imperfections and suffering. In Denktagebuch, Arendt wondered: "Amor Mundi - why is it so difficult to love the world?"3 (Arendt, 2002: 522). Berkowitz, in commenting on Denktagebuch, notices: "It is a judgment that amidst pain, injustice, and heartbreak, we must love the world as it is" (Berkowitz, 2017: 10). Love implies understanding and the reconciliation with the world; without them, love cannot grasp the world's essence, to judge it, and reconcile with it. We love the world with a sense of beauty, and grasp the essence of its phenomena with our ability to judge them. To love the world is difficult because, once it has been understood and judged, it requires efforts to love the world as it is.

Another approach to love is connected with its appearance in public and its following distortion. Arendt emphasized that the only possible space in-between occurs between two lovers and includes only them. The only one who is able to enter that space between both is their child, who is the genuine outcome of love. Only their child is able to bring both lovers back to the world, because their love has transformed into a new beginning, and vanishes after that new beginning. In Denktagebuch, Arendt also defines the end of love as its institutionalization as marriage. The institution of marriage based on love is weaker than the most modern institutions. The reliability of institutions is guaranteed if they are founded on laws rather than emotions. On the contrary, love, upon being institutionalized becomes vulnerable. For Arendt, love is an event that can become a story or fate (Arendt, 2002: 49), but it exists only in the private realm, in that space in-between. Arendt mentioned Nietzsche's reflections about marriage and friendship, and argues that the criteria of friendship cannot be transformed into criteria for marriage (Ibid.: 50). Friendship cannot endure that close distance between people that love can. Thus, the main features of love are its worldlessness and essential absence of distance between lovers. Each time Arendt mentions love in her works, she underlines its irrelevance for the public sphere, since they cannot coexist.

3. "Amor Mundi - warum es ist so schwer, die Welt zu lieben?" 


\section{Fear as Potential Courage}

Whereas love and compassion are antipolitical forces that destroy the common world due to their negation of the space between, fear is "an antipolitical principle within the common world" (Arendt, 2005b: 68). Fear is not a principle of action, but rather an impotence of any actions. Arendt emphasized that every human may experience limits of the potentiality to act at times. Fear has a close connection to the powerlessness in the public domain, and its appearance is determined by various outside conditions, for instance, tyranny. Arendt calls the experience of powerlessness fundamental for human beings and their actions, because each action has its limit. In the situation when potential action is limited and cannot be performed, fear arises.

Fear, as well as compassion and love, is a kind of the inner response to the different phenomena in the sphere of appearance. Unlike love or compassion, though, fear is aroused by the presence of others in the common world. Moreover, fear has its reasons and consequences in the public sphere. Considering tyrannies as the destruction of togetherness of men, Arendt shows that the reasons of powerlessness can be established in those cases when people are artificially separated from each other, staying alone with their fear and unable to assist each other. Tyranny as a weak political order is founded precisely on those humans' isolation. Tyranny is considered as weak because of "the impotence and futility to which it condemns the rulers as well as ruled" (Arendt, 1998: 202). Arendt recalls Montesquieu and his definition of tyranny as one that is based on isolation due to mutual fear and suspicion among people. Isolation causes the destruction of plurality, the crucial condition of speaking and acting together in the public realm. Therefore, fear prevents humans' capacity to speak and act together, and the ability to organize a political community.

When fear enters the public space, it becomes an antipolitical principle that implies the existence of inequality and wrongs. Fear is not aroused in those public realms where human beings can be equal participants in common world affairs. The overcoming of fear causes courageous appearances in the public space. Arendt underlines that the "courageous man ... has decided that fear is not what he wants to show" (Arendt, 1981:36), even while he still has fear inside and cannot overcome it once and for all. However, people can hide it as well as other emotions, and demonstrate what they desire to. Such an ability of fear to be transformed into fearlessness indicates the inherent ability of any person to speak and act in public. Courage being revealed in public becomes a crucial premise for political action. For Arendt, who admired the ancient polis and its heroes, courage was considered as an important political virtue. Arendt emphasized that "whoever entered the political realm had first to be ready to risk his life" (Arendt, 1998: 36); it was courage that helped to overcome the common urgencies of life, to be liberated from labor and work, namely, from all of the inevitable processes of biological life, in order to dedicate one's life to the affairs of the whole, of the polis. Thus, fear of speech and actions indicates the potentially-corrupted public sphere, while its concealment causes the appearance of the courage necessary for politics. 


\section{Conclusion: Understanding Instead of Emotions}

Hannah Arendt considered emotions and their appearance in the public sphere as superfluous and corrosive, leading to the negation of the distance between people and their plurality. Justifying plurality is the crucial task for Arendt, because plurality for her is the main condition of human life, and the line which reads "the fact that men, not Man, live on the earth and inhabit the world" (Ibid.: 7) determines her theory. Therefore, most previous political or philosophical attempts to eliminate plurality got her critiqued and her works received even further careful analysis. Besides this, emotions themselves turned out to be an obstacle to plurality. According to Canovan's interpretation, Arendt was always trying to establish the bulwarks against totalitarianism, and in order to withstand it, she relied on the inner dialog of thinking and the plurality of human beings. Thus, emotions are not able to protect against injustice, cruelty, and violence; emotions cannot become the foundation of political organization or public space.

The main drawback of emotions is their inability to perceive the world as it is since they always are focused on the certain objects. The understanding of the world and a reconciliation with it are crucial for the existence of plurality. Plurality is manifested by means of speech and actions, but it is not possible to achieve it without an understanding of the world as it is. Emotions may influence the perception of various phenomena, or allow to pay special attention to some of these phenomena, but they do not partake in the unending process of understanding, that specifically-human's "way of being alive" (Arendt, 2005a: 308). Understanding and reconciliation with reality are the ways of being at home in the strange world. Reconciliation with the world as such, including the wrongs and the injustice in it, turns out to be not a simple sufferance of events, but understanding the world in which such things are possible. Understanding is essential for politics since it influences the manifestation of the common world of unique and distinct individuals. In Denktagebuch, Arendt emphasized that "understanding is the specifically political way of thinking ("the other's fellow point of view") ${ }^{4}$ (Arendt, 2002: 332); therefore, understanding is the way of coexisting with others to maintain that necessary distance in order to speak with and act among them. Thus, understanding and reconciliation imply the constant presence of others since they both "open the door to politics amidst a world of plurality" (Berkowitz, 2017: 20).

The significant difference between reconciliation with the world and those emotions felt towards it is the sense of reality. Reconciliation in Arendt's sense is bound with the real world as it is, while emotions are always focused on certain objects or parts of the world even though they may distort it. Emotions are able to indicate certain phenomena, although unlike understanding, they never grasp their essence. Arendt underlined that understanding is "the only inner compass we have" (Arendt, 2005a: 323) that allows people to be at home in this world and share it with others. Arendt mentioned King Solomon's "understanding heart" in order to demonstrate its political meaning: "['the understanding heart'] and no mere reflection or mere feeling, makes it bearable for us

4. "Verstehen ist die spezifisch politische Weise des Denkens." 
to live with other people, strangers forever, in the same world, and makes it possible for them to bear with us" (Ibid.: 322). No emotion, even those which are directed towards other people, can be a foundation for the common world; emotions always constitute the private world of their bearers.

Thus, emotions turn out to be obstacles to the existence of the public space and plurality. They are "natural" and inherent human features and cannot be controlled or subdued by the mind, since both have different abilities. Emotions do not make people individuals, as long as the main "individualisers" are their speech and actions in the constant presence of others. Therefore, the world of unique and distinct people cannot be established on the features common to all people, but rather on their unique appearance by means of their speech and action.

\section{References}

Arendt H. (1970) Men in Dark Times, New York: A Harvest Book.

Arendt H. (1981) The Life of the Mind, New York: A Harvest Book.

Arendt H. (1990) On Revolution, London: Penguin Books.

Arendt H. (1996) Love and Saint Augustine, Chicago: The University of Chicago Press.

Arendt H. (1998) The Human Condition, Chicago: The University of Chicago Press.

Arendt H. (2002) Denktagebuch, München: Piper.

Arendt H. (2005a) Essays in Understanding 1930-1954, New York: Schocken Books.

Arendt H. (2005b) The Promise of Politics, New York: Schocken Books.

Arendt H. (2007) The Jewish Writings, New York: Schocken Books.

Berkowitz R. (2017) Reconciling Oneself with Reality, Whatever It May Be: Judgment and Worldliness in Hannah Arendt's Politics. Artifacts of Thinking (eds. R. Berkowitz, I. Storey), New York: Fordham University Press, pp. 9-36.

Birmingham P. (1995) Hannah Arendt's Dismissal of the Ethical. Dissensus Communis Between Ethics and Politics (eds. Ph. van Haute, P. Birmingham), Kampen: Kok Pharos, pp. 131-153.

Birmingham P. (2006) Hannah Arendt and Human Rights, Bloomington: Indiana University Press.

Canovan M. (1992) Hannah Arendt: A Reinterpretation of Her Political Thought, Cambridge: Cambridge University Press.

Degerman D. (2016) Within the Heart's Darkness: The Role of Emotions in Arendt's Political Thought. European Journal of Political Theory. Available at: http://journals.sagepub.com/doi/abs/10.1177/1474885116647850 (accessed 12 October 2018).

Kateb G. (1984) Hannah Arendt: Politics, Conscience, Evil, Oxford: Martin Robertson.

Mahony D. L. (2018) Hannah Arendt's Ethics, London: Bloomsbury Academic.

Nelson D. (2006) The Virtues of Heartlessness: Mary McCarthy, Hannah Arendt, and the Anesthetics of Empathy. American Literary History, vol. 18, no 1, pp. 86-101.

Parekh B. (1981) Hannah Arendt and the Search for a New Political Philosophy, London: Macmillan.

Young-Bruehl E. (2006) Why Arendt Matters, New Haven: Yale University Press. 


\title{
Эмоции в публичном пространстве Ханны Арендт
}

\author{
Яна Лепетюхина \\ Аспирантка Балтийского федерального университета им. Иммануила Канта \\ Адрес: ул. А. Невского, д. 14, Калининград, Российская Федерация 236016 \\ E-mail: iana.lepetiukhina@gmail.com
}

Существенное для политической теории Ханны Арендт разделение частного/ публичного определяет и роль эмоций, часть которых оказывается нерелевантной по отношению к публичной сфере. Частные эмоции, такие как страх, сострадание, любовь и жалость, проявляясь в публичном пространстве, разрушают его. Эти эмоции являются антиполитическими и не имеют отношения к общему миру: они всегда направлены лишь на его конкретные объекты, как, например, сострадание, всегда сосредоточенное на страдании и его причинах. Тогда как публичные эмоции - смех, радость, удовольствие, гнев - являются скорее реакцией на мир в целом, а не на его отдельные части. В статье предлагается анализ первых, антиполитических, эмоций, вмешивающихся в публичные дела и искажающих их. Анализ включает в себя сопоставление эмоций и ключевых понятий теории Арендт, таких как «множественность», «публичное пространство», «уникальность речи и действия», «понимание и примирение с миром». Данный подход позволяет продемонстрировать связь между эмоциями и политикой и, кроме того, указать на альтернативы эмоций в политической сфере, например, солидарность вместо сострадания, или мужество вместо страха. Цель представленной работы - исследовать, как благородные и неотъемлемые в частной жизни эмоции способны разрушить мир общий, в отличие от понимания и примирения с миром, без которых невозможны множественность и публичное пространство, чье существование критично для Арендт.

Ключевые слова: Ханна Арендт, эмоции, сострадание, солидарность, публичное пространство, страх, любовь, понимание 